\title{
UNKNOWN FRAGMENT OF KING SIGISMUNDUS III'S DIARY ABOUT CAMPAIGN TO RUSSIA, 1609-1611
}

\author{
Igor O. Tyumentsev \\ Russian Presidential Academy of National Economy and Public Administration, Volgograd, Russian Federation \\ Nataliya A. Tupikova \\ Volgograd State University, Volgograd, Russian Federation \\ Stanislav V. Mirsky \\ Russian Presidential Academy of National Economy and Public Administration, Volgograd, Russian Federation
}

\begin{abstract}
Events of the Time of Troubles of the early $17^{\text {th }}$ century played a great role in the history of Russia. In the year of 1609, the Polish royal army under high command of hetman Stanislav Zholkevsky and the King Sigismundus III himself invaded Russia and resiged Smolensk. At this time, a massive offensive to Western, SouthWestern and North-Western regions of Russia was launched by some detachments under Aleksander Korvinus Gosievsky, some of Polish colonels who were at the head of their regiments and the Cossacks of Zaporozhye. The role of this invasion was very important. The Polish authorities viewed the Russians as a potentially oppositional force, though actual economic collapse and repressions from the state authorities of Vasily Shuiski and the false Dimitry II considerably undermined their enthusiasm and brought social apathy among the Russians. Nevertheless, a garrison of Smolensk refused to surrender and decided to fight against the enemy. History of this siege was described by the King's secretaries in King Sigismundus III's Diary about Campaign to Russia. It belongs to the main sources about Russia's Time of Troubles and about these events, as well as other documents of foreign observers. Using the procedures developed by R.G. Skrynnikov and I.O. Tyumentsev, the authors found and analysed unknown fragment of the "King Sigismundus" journal", which are edited in this publication for the first time. Comparison of this document with the another data of King Sigismundus III's Diary about Campaign to Russia and other Polish-Luthuanian sources from the beginning of the $17^{\text {th }}$ century enables them to carry out a complex examination of the materials and to cross-verify their data. Experience shows that this technique works effectively.

Key words: Time of Troubles, Russian-Polish relations, Sigismundus III Vasa, hetman Stanislav ¿े: Zyikievsky, starosta of Vielizh, Aleksander Korvinus Gosievski, siege of Smolensk, Bielaya fortress, Polishضi Lithuanian royal army.

Citation. Tyumentsev I.O., Tupikova N.A., Mirsky S.V. Unknown Fragment of King Sigismundus III's Diary about Campaign to Russia, 1609-1611. Vestnik Volgogradskogo gosudarstvennogo universiteta. Serija 4, Istorija. Regionovedenie. Mezhdunarodnye otnoshenija [Science Journal of Volgograd State University. History. Area Studies. International Relations], 2017, vol. 22, no. 4, pp. 91-108 (in Russian). DOI: https://doi.org/10.15688/ jvolsu4.2017.4.9

\section{НЕИЗВЕСТНЫЙ ФРАГМЕНТ ДНЕВНИКА ПОХОДА КОРОЛЯ СИГИЗМУНДА ІІІ В РОССИЮ 1609-1611 ГОДОВ}

\section{Игорь Олегович Тюменцев}

Российская академия народного хозяйства и государственной службы при Президенте Российской Федерации, г. Волгоград, Российская Федерация 


\section{Наталия Алексеевна Тупикова}

Волгоградский государственный университет, г. Волгоград, Российская Федерация

\section{Станислав Викторович Мирский}

Российская академия народного хозяйства и государственной службы при Президенте Российской Федерации, г. Волгоград, Российская Федерация

Аннотация. Авторам удалось обнаружить и проанализировать неизвестный фрагмент «Дневника похода короля Сигизмунда III в Россию» - важного источника по истории Смутного времени начала XVII века. Выдвинута гипотеза, что при создании этого памятника использовались ранние дневниковые записи и архивные документы. Выявлены новые сведения о том, как часть польско-литовских войск была направлена изпод Смоленска против царской правительственной армии и союзного наемного корпуса.

Вводная статья написана И.О. Тюменцевым и С.В. Мирским. Подготовка текста фрагмента на польском языке и перевод с польского языка на русский выполнены Н.А. Тупиковой. Палеографический анализ источника, подготовка текста фрагмента на польском языке с привлечением текста публикации Я. Былинского и комментарии составлены С.В. Мирским.

Ключевые слова: Смутное время, русско-польские отношения, Сигизмунд III Ваза, гетман Станислав Жолкевский, велижский староста Александр Корвин Гонсевский, осада Смоленска, крепость Белая, польсколитовские королевские войска.

Цитирование. Тюменцев И. О., Тупикова Н. А., Мирский С. В. Неизвестный фрагмент дневника похода короля Сигизмунда III в Россию 1609-1611 годов // Вестник Волгоградского государственного университета. Серия 4, История. Регионоведение. Международные отношения. - 2017. - Т. 22, № 4. - С. 91-108. - DOI: https:/ /doi.org/10.15688/jvolsu4.2017.4.9

История Смутного времени начала XVII в. и поход Сигизмунда III в Россию 1609-1611 гг. давно привлекают внимание историков. В начале XVII в. король Речи Посполитой неоднократно заявлял о намерении вмешаться в русские дела $[21 ; 26 ; 28 ; 29 ; 71]$. Ситуация вокруг Московского государства обрела особую актуальность в 1608 - первой половине 1609 года [61; 92]. По мнению Я. Мацишевского, вопрос о вторжении в Россию не ставился в открытую на сеймах тех лет [76, с. 138-139; 77]. Проанализировав ряд документов, в том числе 13 сеймовых инструкций, мы пришли к выводу, что он обсуждался, но большинство участников сеймиков занимали выжидательную позицию [31; 35]. Только договор царя В.И. Шуйского со шведами и превращение авантюры Лжедмитрия II в затяжную войну на истощение заставили польсколитовские власти поспешить с планом подготовки похода на Смоленск [26, с. $547 ; 52$, c. $310 ; 53$, с. $34-35 ; 65$, с. $141-142] .18$ (28) мая 1609 г. король объявил о намерении начать военные действия $[55 ; 63$, с. $3-4 ; 65$, с. $143 ; 96$, c. 23]. 27 августа (6 сентября) в Смоленск был направлен манифест с предложением о сдаче города. 11 (21) сентября войска Речи Посполитой перешли границу. Их численность со- ставляла всего 3620 человек. Лишь 1 октября к ним присоединились около 5 тыс. воинов из Великого Княжества Литовского и немного казаков $[34 ; 49$, с. $21 ; 56$, с. 47]. Смоляне во главе с воеводами боярином М.Б. Шеиным и кн. П.И. Горчаковым отказались пустить врага в город. История осады крепости описана секретарями Сигизмунда III в «Дневнике похода короля» $[39 ; 40 ; 44 ; 52$, с. $314-316 ; 56$, с. 47 $48 ; 76$, c. $209 ; 89$, c. 180$]$.

Подлинник «Дневника» не сохранился. Первые фрагменты из него были напечатаны в Вильно уже в 1610 году. Они охватывали события с 8 (18) августа 1609 г. по 5 (15) апреля 1610 года [60]. Во второй половине XVIII в. А. Нарушевич обнаружил в библиотеке Залусских рукопись «Дневника» с описанием событий 8 (18) августа - 5 (15) октября 1609 г. за подписью С. Бельского. Он снял копию рукописи и использовал извлечения из нее в своих разысканиях. В конце XVIII в. библиотека Залусских была вывезена А.В. Суворовым в Санкт-Петербург, где вошла в состав Императорской публичной библиотеки. Копия А. Нарушевича была найдена и издана в Польше Р. Подберским [58]. Вслед за первооткрывателем издатель посчитал автором источника С. Бельского, но как справедливо 
заметил польский историк Я. Былинский, текст во многих местах отличен от более ранних копий из Ягеллонской Библиотеки, а также Библиотек Чарторыйских и Рачинских [32; $37 ; 39 ; 40 ; 45-47 ; 56$, с. 52]. Рукописные копии содержат отрывки воспоминаний С. Жолкевского и писем гетмана королю [79, с. 2930; 84, c. $528 ; 85$, с. $198-203 ; 96$, с. 134]. Еще один фрагмент (9-14 января 1610 г.) из рукописи Пулавской библиотеки опубликован вместе с письмами С. Стадницкого и анонимного корреспондента в 1847 году [27; 59]. Полный текст «Дневника» впервые издал М.О. Коялович в 1872 году. Он практически идентичен содержанию рукописи Ягеллонской библиотеки. К сожалению, в издании М.О. Кояловича присутствует ряд искажений и пропусков, вызванных цензурными соображениями, а также неточности в публикации польского текста и в переводе [22]. Последнее на сегодняшний момент научное издание источника выполнено Я. Былинским в 1999 году. На наш взгляд, оно является самым удачным. Историк не согласился с названием, которое дал при публикации произведения М.О. Коялович («Поход его королевского величества в Москву 1609 г.»), и предпочел вернуться к оригинальному названию. В соответствии с требованиями современной археографии, в основу текста он положил самую раннюю подробную копию [40]. Остальные приведены в разночтениях [33; 37; 46].

Исследователь правильно заметил, что все наиболее полные рукописные копии не содержат имени автора. По справедливому предположению ученого, «Дневник» составляли лица из королевского окружения (секретари), участвовавшие в переговорах с посольствами польских тушинцев и русских подданных. В «Дневнике» приведено не только содержание этих переговоров, но и тексты документов (фрагменты писем С. Жолкевского, $Ф$. Крыйского, донесения польских командиров, запорожцев и т. д.). Вместе с тем некоторые выводы исследователя вызывают сомнения. Так, по его мнению, в составлении «Дневника» мог участвовать сам гетман С. Жолкевский и его приближенные, хотя нигде в источниках об этом не говорится. Учитывая конфликт короля с гетманом, участие его и кого-либо из его окружения в прославлении политики короля является маловероят- ным. Признав, что «Дневник» уделяет много места наемникам на службе Лжедмитрия II, издатель оставил без анализа и критики их переговоры с королем в 1609-1610 годах.

Исследователи не заметили или не обратили внимания на фрагмент «Дневника» из Курницкой библиотеки (BK 1539). Он даже не упомянут ни в одной специальной научной работе по данной теме. Между тем текст отличается от других копий и позволяет внести дополнения и уточнения в описание осады Смоленска и процесс подготовки войск С. Жолкевского к походу против союзной армии кн. Д.И. Шуйского и Я. Делагарди [36].

Несколько лет назад с помощью польских коллег мы смогли познакомиться с этой рукописью и обратили внимание на анализируемый текст. Это сборник польских актовых документальных материалов конца XVI - начала XVII в., который написан на бумаге середины XVII в. разными чернилами и несколькими почерками [11]. Копиисты не увидели, что, воспроизводя тексты источников, они переписали некоторые из них дважды, в результате чего между документами рукописи образовались нестыковки и повторы. В верхней части правого края листов идет новая пагинация, тогда как слева оставлена старая. Содержание сборника можно условно разделить на следующие части:

1. Письма Сигизмунда III, К. Радзивилла, Я. Млодзеевского, А. Зборовского, Л. Сапеги, К. Острожского, А.С. Радзивилла, Я.К. Ходкевича и др., вышедшие из правительственных кругов Речи Посполитой и посвященные внутренней политике страны, рокошу М. Зебжидовского и т. д. (1598-1613).

2. Копии документов о внешней политике и русско-польских отношениях времен первой половины правления Сигизмунда III (1587-1606).

3. Польские письма и документы о Смутном времени и солдатских конфедерациях 1612-1614 гг., в том числе письма А. Зборовского Я.П. Сапеге, Л. Сапеги жене, С. Жолкевского пану Строенскому, списки русских бояр и дворян, присягнувших на верность Сигизмунду III в 1610 г., универсалы Ю. Чеклинского и Я. Заливского 1612 г., перечень военных расходов казны Великого Княжества Литовского 1613 г. и пр. 
Документы о Смуте написаны одним почерком и композиционно примыкают друг к другу. Войсковые бумаги 1608-1612 гг. и затем до 1613 г. позволяют проследить судьбу солдат королевских войск и наемников Лжедмитрия II, которые вернулись в Речь Посполитую и получили награды от короля. Копии источников 1587-1606 гг., судя по всему, оказались в составе рукописи при копировании и реставрации, хронологически разделив ее массив на неравные части.

Интересующий нас источник примечателен в первую очередь тем, что только в нем дается перечень отрядов, которые первоначально выступили на помощь гарнизону велижского старосты А.К. Гонсевского, который 13 апреля 1610 г. сумел захватить и затем удерживал крепость Белую - важный стратегический пункт на северо-востоке от Смоленска [22, стб. 569; 56, с. 135]. Полк А. Гонсевского состоял всего из 7 хоругвей (гусарская и казацкая хоругви самого велижского старосты, гусарские хоругви Ш. Гонсевского и С. Конецпольского, татарская хоругвь И. Ассановича и казацкие хоругви Я. Хлусского и Я. Гречины) общим количеством от 1000 до 1160 солдат. Причем, за исключением хоругвей С. Конецпольского и Я. Хлусского, этот полк находился на королевской службе только с июля 1609 года $[8$, с. 7,$9 ; 90 ; 91]$. Таких сил было явно недостаточно для противостояния союзным русскошведским войскам, выступившим из Москвы на помощь Смоленску.

23 апреля (3 мая) 1610 г. кн. М.В. СкопинШуйский неожиданно умер в Москве [6, с. 166; 18 , с. $337 ; 56$, с. 141$]$. Вместо него главнокомандующим стал средний брат царя боярин Д.И. Шуйский. Он сосредоточил русско-шведские союзные войска под Можайском. В качестве подкрепления отрядам Г. Валуева и П. Делавиля в Царево Займище был направлен отряд кн. Ф. Елецкого [9; 10, с. $133 ; 12 ; 42 ; 54$, c. 299 ; 56 , с. $146-147,149 ; 85$, с. $198-204 ; 93$; 94; 95]. В письме королю Сигизмунду III С. Жолкевский определял общую численность русских войск в 30 тыс. чел. [42; 75; 85, с. 198 204]. Еще около 5 тыс., согласно его сведениям, составляли иноземные наемники [42; 75; 85, с. 198-204]. Аналогичные данные представлены в «Дневнике похода короля» [56, с. 157]. Позже, в сочинении «Начало и успех Московс- кой войны», гетман, ссылаясь на свидетельство Д.И. Шуйского, назвал другие цифры - 40 тыс. русских воинов и 8 тыс. наемных солдат [96, c. 137]. В королевском лагере под Смоленском с тревогой наблюдали за развитием ситуации. Распад Тушинского лагеря и затянувшаяся осада Смоленска позволяли сторонникам царя В.И. Шуйского уничтожить небольшую армию Сигизмунда III [80, с. 125-126].

В окрестностях Царевого Займища находились бывшие тушинцы под командованием А. Зборовского, перешедшие на сторону польского короля [4, стб. 155, 162-163; 48, c. 443]. В нижеприведенной копии фрагмента дневника даны точные сведения о намеченных к походу воинских силах. В фрагменте, в отличие от дневника, сообщается, что еще 1 июня 1610 г. на совещании у короля было принято решение отправить на соединение со «зборовцами» для последующего удара по войскам противника следующие отряды: 150 чел.

1. Гусарская рота С. Жолкевского -

2. Конная рота коронного кравчего Я. Даниловича - 100 чел.

3. Рота кн. Я. Порыцкого - 100 чел.

4. Рота брацлавского старосты Я. Потоцкого - 100 чел.

5. Рота хмельницкого старосты М. Струся - 100 чел.

6. Рота А. Балабана - 100 чел.

7. Рота М. Гербута - 100 чел.

8. Рота М. Малинского - 100 чел.

9. Гусарская рота Ш. Копычинского 100 чел. 100 чел.

10. Конная рота Я. Невядомского -

11. Конная рота С. Хвалибога - 100 чел.

12. 400 пехотинцев.

13. Пехотная рота С. Жолкевского 100 чел.

14. Пехотная рота Я. Даниловича 100 чел.

15. Пехотная рота Я. Потоцкого - 60 чел.

Хотя отдельные дворяне и дети боярские готовы были признать власть короля, перебежчики из Смоленска утверждали о множестве смертей в городе, а велижский староста А. Гонсевский регулярно сообщал о неурядицах в Москве, судьба всего похода Сигизмунда III буквально висела на волоске. От- 
правка сводного корпуса гетмана С. Жолкевского навстречу вражеским войскам еще больше ослабила осаждающих. Брацлавский воевода М. Потоцкий опасался флангового удара русских войск и был вынужден постоянно держать королевские отряды под Смоленском в состоянии полной боевой готовности. В этой ситуации любая ошибка могла обернуться для польской стороны катастрофой.

С. Жолкевский смог выступить из-под Смоленска только 6 (16) июня 1610 года [4, стб. $155,162-163 ; 5 ; 22 ; 24 ; 48$, с. 443]. Узнав, что союзники идут к Белой, он, как видно из приведенных в анализируемом фрагменте данных, срочно вызвал на помощь из главного лагеря дополнительные силы:

1. Гусарская резервная рота -250 чел.

2. Рота тлумачского старосты пана Гербута -100 чел.

3. Рота слонимского старосты Я.С. Сапеги -100 чел.

4. Рота сондецкого старосты С. Любомирского - 200 чел.

5. Рота А. Олизара Волчкевича - 100 чел.

6. Гусарская рота пана Щита - 100 чел.

7. Четыре роты пятигорцев (400 чел.).

8. 1000 пехотинцев.

Спасти положение помог только полк А. Гонсевского, отразивший два последовательных штурма Белой, которую безуспешно пытались захватить наемники под командованием Э. Горна [7, с. 116-119]. В субботу 5 июня 1610 г. гарнизон крепости отбил первую атаку, уничтожив 90 солдат противника и захватив живыми 20 человек. В понедельник, 7 июня, союзники предприняли новый штурм, но потеряли более 100 воинов и отступили от города. Моральный дух наемных отрядов Я.П. Делагарди, Э. Горна и П. Делавиля упал. Появились случаи перехода солдат на сторону врага. Рядовые наемники требовали денег, но, узнав о приближении войска С. Жолкевского, якобы не хотели брать аванс в размере 3 руб. на человека $[2 ; 3$, с. $104 ; 5$, с. $165 ; 6$, c. $167 ; 9 ; 18$, c. $352-353 ; 54$, c. $299 ; 66$, c. 72 ; $73 ; 75 ; 80$, c. $125 ; 81$, c. $300 ; 96$, c. 128$]$. Pacчетливый Я. Делагарди обещал выплатить все долги после победы. Оплату смогли бы получить лишь те, кто останется в живых. В то же время масштабы разложения не стоит преувеличивать. Основная масса западноевро- пейских наемников была готова сражаться на стороне правительства царя В.И. Шуйского против королевских войск.

Сделанные наблюдения позволяют прийти к выводу, что анализируемый фрагмент дневника похода короля является более ранним текстом, нежели его беловик. Он содержит ценную информацию об обстоятельствах и деталях подготовки Клушинского сражения, закончившегося для союзнической армии катастрофой. Авторы дневника в работе над беловиком сосредоточились на главном и эту ценную информацию опустили, представив победу королевских войск неизбежной. Все эти наблюдения делают актуальными выяснение источников дневника и направления редакторской работы его авторов.

В основу публикации положен текст анализируемого источника. Дефектные места частично восстановлены с помощью публикации Я. Былинского и соответствующих фрагментов списков дневника из Ягеллонской Библиотеки (BJ) и Библиотеки Рачинских (BR). B разночтениях помещены дополнительные сведения из этих списков, которые отсутствуют как в публикуемом источнике, так и в издании Я. Былинского [19].

Автором приведенного фрагмента «Дневника» использовалась бумага folio с филигранью в виде двуручного кувшина. В связи с тем, что водяные знаки сохранились лишь частично, их полная идентификация не представляется возможной. Для написания документа использовались гусиные перья и чернила черного цвета. В данный момент документ находится в ветхом состоянии, и чернила от времени частично потускнели. Пометы на лицевой части документа сделаны архивистами чернилами и простым карандашом. Это цифры пагинации и их изменения, вызванные включением в дело новых материалов. Определенную ценность имеют записи польских архивариусов, предваряющие и заключающие текст источника, которые свидетельствуют, что архивисты, в целом понимая содержание текста, не смогли точно определить дату и обстоятельства описываемых событий.

Орфография и пунктуация приведены в соответствие с современными нормами. Для объяснения сложного повествования использовался знак «:» Для выделения фраз, являю- 
щихся чаще всего объяснением чего-либо, использован также знак «-».

Личные имена и топонимы воспроизводятся в авторской транскрипции. Окончания заимствованных латинских слов («kontinuacya») даются в соответствии с инструкцией [67, c. 605-607]. Употребление прописной буквы ограничено именами собственными (лица и географические объекты). Формулы речевого этикета и именования, замещающие имена собственные, приводятся строчными буквами: jmć - jego (jej) mość (сокращенное miłość); jmci - jego (jej) mości (miłości).

В отношении к королевской особе использовано нормативное применение полной формы в сокращении:

JKM - jego królewska miłość;

JMK - jego miłość król;

KEM - król jego miłość.

В тексте источника нами приняты следующие обозначения:

- ( ) для выделения фраз, включенных в более длинное высказывание;

- <> для исправления (адаптирования) лексических и грамматических особенностей; исправлены (адаптированы) для читателя (особенно российского) беспредложные конструкции (типа "Lecz nikt się zamku nie pokazał", то есть z zamku, или в зависимости от контекста: w zamku) и т. п.;

- [ ] для обозначения всякого рода дополнений текста;

- \{\} для выделения слов и фраз, дописанных между фрагментами основного текста и на полях.

В русском переводе латинские выражения, так же как в польском тексте, даны курсивом. Использованы сокращения:

п. - пан;

е.м.п. - его милость пан;

ЕКМ - его королевская милость;

ЕМК - его милость король;

KEM - король его милость.

\section{Текст $^{1}$}

29 maja. Odprawiono posłów od tamtego wojska, daws(z)y im na piśmie respons.

Tegoż dnia z Rygi<do obozu > przyprowadzono armatę mianowicie babę, bazyliszka i 6 braci $<$ sztuk dość chędogich i mocnych $>2$.
Przyprowadzili ${ }^{3}$ kozacy bojarzyna jednego spod Możajska, który bojarów tych, co do KJM się chcieli przedać, odprowadził do stolice [na zajadączego] (pod Możajskiem ${ }^{4}$ porwali). Ten, o śmerci Skopinowej twierdząc, na jego miejscu Dymitr Szujski z Szeremieczem, hetmanem, powiada wiesz(n)cz o wielkim rozerwaniu między bojarzy po śmerci Skopinowej i insze pewne przestrogi dowodne, [bo świeżo z Moskwy wyjachał. Privatim powiada].

(Ultima $)^{5}$ maja - nihil dignum notatu ${ }^{6}$.

(1) iuny. Tajemna rada ${ }^{7}$ u KJM była, gdzie (jmci) p. hetmana KJM naznaczył <na posiłek> tamtemu wojsku, które pod Czarowym Zajmiszczem leży przeciwko liudziom Szujskiego, który snać na odsiecz Smoleńskowi idzie, <też z tych ins(z)y ida roty samego jmci p. hetmana choragiew, pod którą 150 kopijnika, p. krojczego koronnego 100, ks(ię)cia p. Poryckiego100, p. starosty brasławskiego 100 , p. starosty chmielnickiego 100, p. Bałabanowych 700, p. ... rewych ${ }^{8} 100$, p. Herbuta 100, p. Malińskiego 100, kopijnikow p. Kopyczyńskiego ${ }^{9}$, p. Niewiadomskiego koni 100, p. Chwalibogowych koni 100 , piechoty rajtarów 400, samego p. hetmana 100 , p. krojczego 100 , p. starosty brasławskiego $60>10$.

Bojarowie [z posadzkimi ludźmi] z Mieszczowska ${ }^{11}$ u JKMci <przez kozaki zaporoskie gwałtem wzięci, przyszli chrest na imię królewskie całując $>$ podając wiarę i poddaństwo swe byli.

Przedał się moskwicin (z) zamku jeden, który o \{wielkim\} ${ }^{12}$ powietrzu i chorobach w zamku, $<$ także od niedziele przeszłej do czwartku 200 zdochło, a zdrowych ledwie jest $1000^{13}$, chorych 3000, jakoż i ten, co się przedał, twarzy opuchłej, nędznej tak, że śmierci podobien, widząc i z szańc(z)ów p. marszałkowych, że co dzień suneralia ${ }^{14}$ odprawują ${ }^{15}>$.

Dał znać jmć p. starosta wieliski, iż kozacy, których (po)syłał pod Tor[opiec] ${ }^{16}$ i Rżow, takiego dostali języka: że na Rżowie kilkadziesiąt tylko ${ }^{17}$ jest Moskwy $<\mathrm{z}$ bojarynem jednym. Bojarowie $\mathrm{z}$ Nowogródka Wielkiego po śmierci Skopina rozbiegli się do domów swych, o wojsku tam żadnym nie słychać, Skopin umarł, że w Moskwie wielkie między Moskwą roz(p)rośnienie, że kilkadziesiąt bojarów smolan, pobaczywszy nierząd, chcieli do KJM, ale Szujski, postrzegszy, kazał ich pojmać i pomordować, ich miewał 
każdego imieniem, perswadował aby się poddali, oni przecie(ż) przy uporze swym zostali ${ }^{18}>19$.

\section{Kontinuatyja diariusza}

5 juny. Ku wieczorowi zawołała Moskwa z muru prosząc, aby do nich posłano tego bojarzyna co się z rozkazania Szujskiego przekradał do Smoleńska od naszych pod Możajskiem pojmanego. Posłany powiedał ${ }^{20}$, że odsieczy mieć nie mogą, bo Skopin Szujski umarł, że się ludzie od hospodara rozbiegają $<\mathrm{i}>21$ że lud pospolity i celniejszy bojarowie JKM nastąpienia i królewicza jmci pragna, ale narod krnąb[r]ny wiary dać nie chciał, owszem tego bojarzyna połajał ${ }^{22}$.

Już prawie $\{g d y\}$ wsiadać miał w droge [jmć p. hetman], przyprowadzono dwu Anglików, których pod Białą porwano ${ }^{23}$, ci powiadają, iż Anglików, Szkotów, Niemcó(w) i Francuzów pod Białą 3000 idzie, a kilka tysięc(z)y Moskwy, zaczym nowa consilia musiała nastąpić i kilka rot tak(że) usarskich, jako ${ }^{24}$ pieszych nad pierwe przydano: a co miał prosto do wojska tamtego ku (C)arowemu Zajmiszczu iść, obrócił się ku Białej na odsiecz ${ }^{25}$.

Znowu $\mathrm{z}$ listy od $\mathrm{p}$. starosty wieliskiego przybieżano, w którym już o następując(z)ym nieprzyjacielu znać daje i żejuż w mili tylko od Białej położył się obozem, za czym prosi o przędką ${ }^{26}$ odsiecz. Ruszył się tegoż dnia ku wieczorowi (jmć) p. hetman i w mili ${ }^{27}$ od obozu noc(z)ował.

$<$ Za onym ${ }^{28}$ na zajutr(z) te roty wyszły: (jmci) ${ }^{29}$ p. hetmana choragiew, pod która 250 usara, kniazia (jmci) p. krakowskiego 100, pana koniuszego coronnego ${ }^{30} 100$, kniazia Poryc(z)kiego 130, p. starosty chmielnic(z)kiego 200 , p. starosty thumac(z)kiego 100, p. starosty słonimskiego 100, pana starosty sądec(z)kiego 200 , p. starosty brasławskiego 100 , p. Bałabanowych 100, p. Olizarowych 100 , p. Malińskiego 100, p. Szczytowych 100, kopijnika rajtarów 100, pety(h)orc(z)ów p. Chwaliboga 100, p. starosty sądec(z)kiego 100, p. Niewiadowskiego 100 , p. starosty chmielnic(z)kiego 100, piechoty $1000^{31}>$.

Nadde dniem ${ }^{32}$ kozaków zaporos(z)kich kilku na straży Moskwa, wypadszy $<\mathrm{z}>$ zamku, porwała. Tegoż dnia pacholikowi(e) (nie)którzy po derewniach dla żywności byli przybiegli, dając znać, iż Moskwa, z którymi żyli, przestrzegli ich, że kilka tysięczy Niemc(z)ów i Moskwy do
Smoleńska lasem się przekrada. Zaczym jmć p. wojewoda brasławski, który wojskiem $<$ KJM $>33$ rządzi i straży przyczynił i kilkadziesiąt koni kozaków po gościnc(z)ach na wywiady rozesłał i pilność większą \{koło zamku\} sam będąc in omnes partes interitus miał.

P. Kazanowski przysłał bojarzyna znacznego, świeżo z Moskwy wysłanego. Ten powiada, że (o)koło Szujskiego gryź i w ludzie, i w pieniądze ${ }^{34}$, ludzi więcej ani się spodziewa, ani ma nad Niemc(z)ów z Pontusem $300^{35}$ i tych, którzy pod Białą byli, \{a\} (z) Moskwy najwięc(z)ej i to lada (co) jakich $150{ }^{36}$. Skopin Szujski umarł. Dymitra Szujskiego na jego miejsc(z)e het[manem] dał. Rezańskie ${ }^{37}$ państwo mu rebelizowało i siła ${ }^{38}$ prowincy(jej) go nie słuchają. Ludzie na Moskwie KJM pragną i życzą sobie, aby rychło nastapił.

Tegoż dnia taka przyszła od jmci p. hetmana wiadomość, że p. Gąsiewski, starosta wieliski, w sobotę przeszłą, to jest 5 junii, utarczkę miał z Niemc(z)y pod Białą. Legło 90 Niemc(z)ów na plac(z)u, a $20^{39}$ żywc(z)em wzięto. $<$ Potem w $\operatorname{noc}(z) y>{ }^{40} 16$ ich przedało się do zamku.

W poniedziałek jako 7 junii do szturmu przypuścili, namówiwszy się z tą Moskwą, c(z)o ${ }^{41}$ przy naszych była, \{że kiedy mieli iść do szturmu $\}$, aby w ten że czas zapalili zamek. Ale ci Niemc(z)y, co się przedali w niedzielę, przestrzegli naszych o tej zdradzie, zaczym przypuściwszy do szturmu, a nie (z)obaczywszy ognia c(z)o zamku, poznali, że zdrada odkryta, i tak u tego szturmu 100 i kilkadziesiąt czł(owi)eka zgubiwszy, powróc(z)ili ku Rżowu, gdzie snać jmć p. hetman poszedł im zachodzić ku przeprawie, a p. Gąsiewski, starosta wieliski, owe ${ }^{42}$ Moskwę, co cons(z)c(z)y zdrady byli, do turmy wróc(z)ić ${ }^{43}$ kazał, do dalszej JKM nauki. Kozac(z)y, za się ludzie pospolite moskiewskie, po włości ścinać passim poczęli, stąd że za przyjściem ludzi Szujskiego poczęli już byli żywność do tego tam wojska wozić i po trzech rublach na zaplatę piechocie niemieckiej obiec(z)owali, ale oni, posłyszawszy o p. hetmanie, $\{$ że się ruszył $\}$, i zysku i rubli nie czekali.

$<$ Przedał się moskwic(z)in jeden $<$ z $>$ zamku przede dniem, który powiedział, już ${ }^{44} \mathrm{~W}$ zamku nade dniem wypaść mocno się gotują. Zarazem jmć p. wojewoda brasławski wszystkie rotmistrze obsyłał, aby pogotowiu byli, zaczym po wszystkim 
obozie gotowość wielka była. Lecz nikt się $<\mathrm{z}>$ zamku nie pokazał $>45$.

Tegoż dnia od p. starosty wieliskiego 20 Niemc(z)ów przyprowadzono: 16 - co się przedali, a 4 - co pod Białą w utarcze wzięto.

EMK 46

\section{Перевод}

29 мая. Отправили послов от тамошнего войска ${ }^{47}$, давши им письменный ответ.

Того же дня из Риги доставили пушки, а именно Бабу, Василиска и шесть Братьев ${ }^{48}$, в хорошем состоянии и мощных.

Привели казаки одного боярина из-под Можайска, который из тех бояр, что хотели перейти к КЕМ, походил снаружи на заезжего. Под Можайском схватили. Этот, твердя о смерти Скопина ${ }^{49}$ (и что) на его месте Димитрий Шуйский ${ }^{50}$ с Шереметевым ${ }^{51}$, сообщает гетману ${ }^{52}$ известие о великом раздоре между боярами после смерти Скопина и иные некоторые доказательные свидетельства, поскольку недавно выехал из Москвы. Лично сообщает.

В последний день мая - ничего, достойного записи.

(1) июня. Был тайный совет у КЕМ, где е.м.п. гетмана КЕМ назначил в помощь тамошнему войску, которое стоит под Царевым Займищем против людей Шуйского, которые, верно, идут на выручку Смоленску. Также из этих другие идут роты - самого е.м. п. гетмана хоругвь, под которой 150 копейщиков пана кравчего коронного ${ }^{53} 100$, кн. п. [По]рыцкого ${ }^{54} 100$, п. старосты брацлавского ${ }^{56} 100$, п. старосты хмельницкого ${ }^{57} 100$, п. Балабана 700 , п. (...) 100, п. Гербута ${ }^{58} 100$, п. Малинского ${ }^{59} 100$, копейщиков (п. Копычинского), конных п. Невядомского ${ }^{60} 100$, конных п. Хвалибога ${ }^{61} 100$, пехоты рейтаров 400 , самого п. гетмана 100 , п. кравчего 100 , п. старосты брацлавского 60.

Были бояре из Мещерска у ЕМК, чтобы выказать свое подданство и верность.

Перебежал один московит из крепости, который о великом моровом поветрии и болезнях в крепости (сообщил), а также что от прошлого воскресенья до четверга 200 сдохло, а здоровых едва имеется 1000, больных 3000 , как и этот, который перебежал, с опухшим лицом, такой горестный, что смерти по- добен, видно это и из окопов п. маршалка ${ }^{62}$, что ежедневно разведку проводят.

Дал знать е.м.п. староста велижский ${ }^{63}$, что казаки, которых он посылал под Тор[опец] и Ржев, взяли такого языка (который сообщил): что в Ржеве только несколько десятков есть московитов с одним боярином, бояре из Великого Новгорода после смерти Скопина разбежались по своим домам, о войске там ни о каком не слыхать, Скопин умер, что в Москве великий между московитами разброд, что несколько десятков бояр-смолян, увидев безвластие, хотели перебежать к КЕМ, но Шуйский, узнав, приказал их поймать и убить, неоднократно их каждого от своего имени убеждал, чтобы подчинились, они все же остались непреклонны.

\section{Продолжение дневника}

\section{5 июня}

Перед вечером московиты закричали со стены, прося, чтобы к ним послали этого боярина, нашими пойманного под Можайском, что по приказу Шуйского прокрадывался к Смоленску.

Посланный поведал, что выручки получить не могут, так как Скопин-Шуйский умер, что люди от государя разбегаются и что весь простой люд и виднейшие бояре хотят на престол ЕКМ и е.м. королевича. Но местный люд не захотел ему поверить и этого боярина, напротив, обругал.

Уже почти когда в дорогу тронуться должен был [Жолкевский], привели двух англичан, которых похитили под Белой. Эти говорят, что англичан, шотландцев, немцев и французов идет под Белую 3000 и несколько тысяч Москвы, после чего новый замысел должен был осуществиться, и несколько рот также гусарских, как и пеших прежде, добавлено. Несмотря на то, что [Жолкевский] должен был прямо до тамошнего войска идти к Цареву Займищу, [он] повернул к Белой на выручку.

Снова с письмом от п. старосты велижского прибыли, в котором [тот] дает знать уже о наступающем неприятеле, и что уже в мили только от Белой расположился обозом, из-за чего просит о быстрой подмоге. Е.м.п. гетман двинулся к вечеру этого же дня и в мили 
от лагеря заночевал. За ним утром вышли эти роты: е.м.п. гетмана хоругвь, под которой 250 гусаров, кн. е.м.п. краковского ${ }^{64} 100$, п. конюшего коронного 100, кн. Порыцкого 130, п. старосты хмельницкого 200, п. старосты тлумачского 100 , п. старосты слонимского ${ }^{65}$ 100 , п. старосты сондецкого ${ }^{66} 200$, п. старосты брацлавского 100, п. Балабана 100, п. Олизара 100, п. Малинского 100, п. Щита ${ }^{67} 100$ копейщиков, рейтаров 100, пятигорцев п. Хвалибога 100 , п. старосты сондецкого 100 , п. Невядовского 100, п. старосты хмельницкого 100 , пехоты 1000.

Перед рассветом московиты, напав из крепости, похитили нескольких запорожских казаков на карауле. В этот же день пахолики, которые были в деревнях за продовольствием, прибежали, давая знать, что московиты, с которыми [они] жили, предупредили их, что несколько тысяч немцев и московских [людей] прокрадываются лесами к Смоленску. После чего е.м.п. воевода брацлавский, который возглавляет войско, и караулы добавил, и несколько десятков конных казаков на дороги для разведки разослал, и усердием, будучи один, известия от каждой части (войска) имел.

П. Казановский ${ }^{68}$ прислал видного боярина, недавно отправленного из Москвы. Этот рассказывает, что около Шуйского грызня и из-за людей, и из-за денег. Людей больше и не ожидается, и нет, немцев с Понтусом ${ }^{69} 300$ и тех, которые были под Белой, а московитов самое большее, и то каких-то негодных, 1500. Скопин-Шуйский умер. На его место гетманом поставил[и] Димитрия Шуйского. Рязанцы против него взбунтовались, и многие провинции его не слушают. Люди на Москве требуют КЕМ и желают для себя, чтобы [он] быстро взошел на престол.

В этот же день пришла такая весть от е.м.п. гетмана, что п. Гонсевский, староста велижский, в прошлую субботу, то есть 5 июня, имел стычку с немцами под Белой. Полегло 90 немцев на поле битвы и 20 взято живыми. Потом, ночью, 16 их убежало в крепость.

В понедельник, 7 июня, предполагали штурм, договорившись с теми московитами, что при наших были, чтобы в это же время они зажгли крепость. Но те немцы, что убежали в воскресенье, предупредили об этой измене наших, после чего, предполагая штурм, но, не уви- дев огня в крепости, узнали, что измена раскрыта, и так, в этом штурме 100 и несколько десятков человек потеряв, повернул[и] на Ржев, куда, верно, е.м.п. гетман пошел, прежде чем заходить к переправе. А п. Гонсевский, староста велижский, тех московитов, что причастны к измене были, приказал бросить в тюрьму, что послужит им уроком. Казаки же, те, что родом из московского простого люда, волости притеснять начали, оттуда же после прихода людей Шуйского начали до тамошнего войска продовольствие возить и по три рубля плату немецкой пехоте обещано, но они, услыхав о п. гетмане, ни выгоды, ни рублей не ожидали.

Перебежал московит один из крепости на рассвете, который рассказал, что из крепости перед восходом готовятся неожиданно мощно ударить. Е.м.п. воевода брацлавский одновременно послал ротмистров в сотни, чтобы были в готовности, из-за чего во всем лагере готовность была большая. Но никто из крепости не показался.

Того же дня от п. старосты велижского 20 немцев препроводили: 16 - что перебежали, а 4 - что под Белой в стычке взяли.

EMK

\section{ПРИМЕЧАНИЯ}

${ }^{1}$ При подготовке документа мы руководствовались правилами, изложенными в Instrukcji wydawniczej dla źródeł historycznych od XVI wieku do połowy XIX wieku (pod red. K. Lepszego. Wrocław, 1953), с незначительными от них отступлениями. При подготовке текста на русском языке мы использовали принципы издания, принятые в серии «Памятники истории Восточной Европы» (Москва - Варшава) [12; 14], позволяющие максимально адаптировать текст для восприятия широким кругом читателей как в России, так и в Польше.

2 Текст неразборчив, восстановлено по отсутствующему в публикации Я. Былинского фрагменту источника самой ранней полной копии [34].

${ }^{3}$ Diariusz drogi króla (далее везде - D): przyprowadzono.

${ }^{4}$ Во второй, более поздней подробной копии BR Rkps. 33, K. 328 r. - w Moskwie.

${ }^{5}$ BR Rkps. 33, K. 328 r. - 31. Nihil dignum.

${ }^{6} \mathrm{D}$ : in silentio transacta.

${ }^{7} \mathrm{D}$ : konsultacja prywatna.

${ }^{8}$ Одно слово написано неразборчиво.

9 Текст неразборчив, чтение предположительное. 
10 BD нет.

11 B BR. Rkps. 33. K. 328 r.: Mieszczerska.

12 BD нет.

${ }^{13} \mathrm{BD}-2000$.

14 Текст неразборчив, чтение предположительное.

15 B D нет.

16 Восстановлено по: D. S. 146.

17 B BJ Rkps. 102, K. 356: ledwo.

18 BD нет.

19 BR Rkps. 33, K. 328 r. - 328 v.: «Bojarzyna tego, którego spod Możajska przyprowadzono z szańców na gowor wysadzono, ten perswadować począł do podania zamku, powiedając, że sila bojar jest życzliwych KJMci i odejść od Szujskiego chcieli, specifice każdego namawiał, przecie(z) przy swoim zostali uporze. Już prawie gdy wsiadać miał jmć p. hetman w drogę, przyprowadzono dwóch Anglików, których pod Białą pojmano. Ci powiadali, iż Anglików, Szkotów, Niemców pod Białą 3000 idzie, a kilka tysięcy Moskwy, zaczym nova consilia nastąpić musiały i kilka rot tak (h)usarskich jako pieszych had pierwsze przydano, miał prosto od wojska tamtego ku Carowemu Zajmiszczu iść, obrócił się ku Białej». См. также: BJ. Rkps. 102.

${ }^{20} \mathrm{D}$ : powiedział.

${ }^{21} \mathrm{BD}$ нет.

22 D: złajał.

${ }^{23}$ D: pojmano.

${ }^{24}$ D: pety[h]orskich i.

${ }^{25}$ BR. Rkps. 33: 5 junii.

26 D: prędka.

27 BJ. Rkps. 102. K. 356: mil.

${ }^{28}$ BR. Rkps. 33: 6junii.

${ }^{29}$ D: nim.

${ }^{30}$ D: krajczego.

${ }^{31}$ BR. Rkps. 33: «Zanim nazajutrz roty wyszły, jmci p. hetmana choragiew pod którą 250 (h)usarza księcia jmci p. krakowskiego 100, p. krajczego kor. 100, księcia Poryckiego 130,p. starosty chmielnickiego 200, p. starosty bracławskiego 100, p. starosty słonimskiego 100 , p. starosty sądeckiego 200, p. starosty thumackiego 100, p. Sczytowych 100 kopijnika, rajtarów 100, petyhorców p. Chwaliboga 100, p. starosty sądeckiego 100, p. Niewiadomskiego 100, p. starosty chmielnickiego 100, Moskwy 100 koni, piechoty tysiąc»».

32 D: Nazajutrz nade dniem.

33 B D нет.

${ }^{34} \mathrm{D}$ : grosze.

${ }_{35} \mathrm{D}: 3000$.

${ }^{36}$ D: 15000.

37 BR. Rkps. 33. K. 329 r.: Reżańskie (riazańskie).

${ }^{38}$ D: wiele.

39 BR. Rkps. 33. K. 329 r.: 30 żywcem wzięto, a w nocy...

40 D: o północy.

${ }^{41}$ D: $w$.
42 D: one.

${ }^{43}$ D: wrzucić

${ }^{44}$ D: w nocy.

${ }^{44}$ D: iż.

${ }^{45}$ BR. Rkps. 33. K. 329 r.: «Przedał się moskwicin w nocy, który powiedział, że na wycieczkę potężną przygotowali się i już wypadać mają. Zaczym p. wojewoda bracławski wszystkiemu to obwieścił wojsku i do gotowości rozbudził, sam w polu z uszykowaniem stał, czekając ażby się z której bramy Moskwa ukazała, lecz nikogo widać nie było».

46 Подпись неразборчива, чтение предположительное. Возможно, здесь могло быть: Na własne EMK rozkazanie.

47 Речь идет о посольстве А. Зборовского и Я. Бобовского к королю 5 (15)-19 (29) мая 1610 года.

${ }^{48}$ Названия орудий.

49 Кн. М.В. Скопин-Шуйский (8 (18) ноября 1586 - 23 апреля (3 мая) 1610 гг.), русский государственный и военный деятель Смутного времени, организовавший освободительный поход на Москву, осажденную войсками Лжедмитрия II [1; 13; 17].

${ }^{50}$ Кн. Д.И. Шуйский (ок. 1560-1612 гг.), русский военный деятель Смутного времени. После воцарения старшего брата В.И. Шуйского (1606 г.) считался наследником престола.

${ }^{51}$ Кн. Ф.И. Шереметев (ум. 17 (27) февраля 1650 г.), русский боярин, воевода и государственный деятель. Служил царю В.И. Шуйскому. В 1607 г. безуспешно осаждал Астрахань, затем занял Царицын и двинулся вверх по Волге, очищая ее от сторонников Лжедмитрия II. В начале 1610 г. его отряды соединились с войсками М.В. Скопина-Шуйского и освободили Москву [16].

52 С. Жолкевский (1547 или 1550 - 7 октября 1620), польский полководец начала XVII в., польный и великий гетман, затем великий коронный канцлер. Разбив в 1610 г. при Клушине войска кн. Д.И. Шуйского, он подступил к Москве, где в это время был свергнут царь В.И. Шуйский, и добился избрания на московский престол королевича Владислава [30; 96].

53 Я. Данилович (ум. 1628), любельский ловчий, назначенный на должность коронного кравчего 11 (21) декабря 1600 г., затем - львовский каштелян (с 3 мая 1612 г.) и воевода русский [50, с. 64; 70].

${ }^{54}$ Кн. Я. Порыцкий (ок. 1572 - 1615), гусарский ротмистр, иберпольский и клещинский староста [38].

55 Я. Потоцкий (ум. 1611), генеральный староста подольских земель, один из главных инициаторов похода на Смоленск [72].

56 М. Струсь (ум. 1627), хмельницкий, смятинский, коломойский и любачевский староста, участвовал во всех походах Сигизмунда III. После отъезда А. Гонсевского в Речь Посполитую в 1612 г. командовал польским гарнизоном Москвы. После сдачи 
6 ноября 1612 г. попал в плен, где номинально находился до Деулинского перемирия, заключенного 1 (11) декабря 1618 г. и вступившего в силу 3 января 1619 года. Фактически был в плену до 1 июня 1619 г., до обмена под Вязьмой польских пленников на Филарета и его свиту. Впоследствии участвовал в цецорском походе С. Жолкевского, был захвачен татарами и выкуплен при посредничестве депутатов Галицкого сеймика [78, с. 240; 82, с. 639; 87, с. 238-240].

57 А. Балабан (ум. 1637), винницкий, рогатинский и трембовельский староста, ротмистр, затем полковник [57, с. 248].

${ }_{58}$ М. Гербут, каменецкий каштелян, ротмистр и королевский дворянин. Погиб под Москвой во второй половине 1610 года [83, с. 354-355].

${ }_{59} \mathrm{M}$. Малинский, ротмистр королевских войск. Участник одного из посольств к сапежинцам [80, с. $124 ; 86$, с. 170$]$.

${ }^{60}$ Ротмистр коронного войска [96, с. 134].

${ }^{61}$ С. Хвалибог - ротмистр, затем - участник конфедерации так называемого московского войска.

62 То есть позиции отрядов литовского маршалка К.М. Дорогостайского (ум. 1615) [71, с. 331-333].

63 А.К. Гонсевский (ум. 1639), государственный и военный деятель Великого Княжества Литовского, комендант московского Кремля и командир столичного гарнизона в 1610 - начале 1612 г., староста велижский (с 1600 г.), великий референдарий литовский (1610-1625 гг.), великий писарь литовский (1615-1625 гг.), воевода смоленский (16251639 гг.), писарь польный литовский (1630-1639 гг.), староста марковский, пунский и купицкий. В 1606 г. участвовал в польском посольстве к Лжедмитрию I. В мае 1606 г. во время восстания в столице и свержения Лжедмитрия I был задержан в Москве и вернулся на родину только в 1608 году. В 1609 г. принял участие в походе короля Сигизмунда III на Смоленск. В 1610 г., действуя на севере Смоленщины самостоятельно от главных сил королевской армии, во главе собственного отряда взял и удерживал крепость Белую [64, с. 339-340; 69, с. 81-82; 88].

64 Я. Острожский (ок. 1554-1620), волынский воевода, затем - краковский каштелян, старший сын К.В. Острожского и С. Тарновской [51, с. 481-486].

${ }_{65}$ Я.С. Сапега, сын канцлера ВКЛ Л. Сапеги [68, c. 122].

${ }^{66}$ С. Любомирский, сандецкий (1597-1613), добчицкий (1611) и списский (1612) староста [50, c. 238].

${ }^{67}$ Щит - ротмистр гусарской роты.

${ }_{68}$ М. Казановский - полковник, командир полка из 6 хоругвей (гусарские хоругви самого М. Казановского, Я. Скумина - Тышкевича, А. Фирлея и кн. Я. Порыцкого, гусарско-казацкая хоругвь Гвоздиковского и казацкая хоругвь С. Васичинского) общим числом от 584 до 760 солдат. Его полк был сформирован в июле 1609 года. В конце 1609 г. был отправлен в Тушино вместе с посольством, целью которого было принудить польско-литовские отряды отказаться от поддержки самозванца. На протяжении следующих месяцев М. Казановский оперировал на западе от Можайска, в окрестностях Вязьмы и Царева Займища $[8$, с. $1-11 ; 80$, с. $157 ; 90 ; 91]$.

69 Я. Делагарди (10 (20) июня 1583 - 2 (12) августа 1652 г.), шведский военный и государственный деятель, активный участник событий Смутного времени. В 1609 г. возглавлял вспомогательный корпус, отправленный шведским королем Карлом IX на помощь В.И. Шуйскому. Вместе с войсками под командованием кн. М.В. Скопина-Шуйского разбил поляков у Твери, освободил от осады Троице-Сергиев монастырь. После смерти М.В. Скопина-Шуйского был разбит при Клушине и вынужден был отступить. Из-за подчинения московских бояр польскому королевичу Владиславу захватил Новгород, Тихвин и другие города северо-запада России. Сторонник кандидатуры шведского принца Карла Филиппа на русский трон [15; 25].

\section{СПИСОК ЛИТЕРАТУРЫ}

1. Абрамович, Г. В. Князья Шуйские и российский трон / Г. В. Абрамович. - Л. : Изд-во ЛГУ, 1991. $-192 \mathrm{c}$.

2. Акты исторические, собранные и изданные Археографическою комиссиею (АИ). - СПб., 1841. - T. 2. - № 282.

3. Белокуров, С. А. Разрядные записи за Смутное время (7113-7121 гг.) / С. А. Белокуров. - М., 1907. $-343 \mathrm{c}$.

4. Будила, Ю. История ложного Димитрия 1603-1613 гг. / Ю. Будила // Памятники, относящиеся к Смутному времени начала XVII ст. - СПб., 1872. - Т. 1. - Стб. 81-364.

5. Буссов, К. Московская хроника 15841613 гг. / К. Буссов ; пер. с нем. Е. И. Бобровой ; ред. С. А. Акулянц. - М. ; Л. : Изд-во АН СССР, 1961. $400 \mathrm{c}$.

6. Бутурлин, Д. История смутного времени в начале XVII в. : в 3 т. / Д. Бутурлин. - СПб., 1839, 1841, 1846. - Т. III. $-516 \mathrm{c}$.

7. Видекинд, Ю. История десятилетней шведско-московской войны XVII в. / Ю. Видекинд ; пер. С. А. Аннинского, А. М. Александрова ; под ред. В. Л. Янина, А. Л. Хорошкевич. - М. : Памятники исторической мысли, 2000. - 652 с.

8. Война с Польшею в 1609-1611 годах / изд. Ф. Ф. Вержбовский. - Варшава, 1898. - 102 с.

9. Делавиль, П. Краткая записка о том, что происходило в Московии от царствования Ивана 
Васильевича, императора, до Василия Ивановича Шуйского, сочиненная Петром Делавиллем де Ломбаль в 1611 году / П. Делавиль // Русский вестник. Том первый. - СПб., 1841. - С. 744-756.

10. Делавиль, П. Краткое рассуждение о том, что произошло в Московии со времени царствования Ивана Васильевича, императора, до Василия Ивановича Шуйского. Сочинение Пьера Делавиля де Домбаля. 1611 / Делавиль де Домбаль Пьер ; пер. с фр. С. А. Мезина, коммент. Я. Н. Рабиновича // Историографический сборник : межвуз. сб. науч. тр. - Саратов : Изд-во Сарат. ун-та, 2008. - Вып. 23.-С. 124-139.

11. Дианова, Т. В. Водяные знаки рукописей России XVII в.: (По материалам Отдела рукописей ГИМ) / Т. В. Дианова, Л. М. Костюхина. - М. : Наука, 1980. - № 1255-1257, 1261-1262.

12. Дневник Яна Петра Сапеги (1608-1611 гг.) / сост. И. О. Тюменцев, М. Яницкий, Н. А. Тупикова, А. Б. Плотников // Памятники истории Восточной Европы. Источники XV-XVII вв. - М. ; Варшава : Древлехранилище, 2012. - Т. 9. - 455 с.

13. Каргалов, В. В. Московские воеводы XVIXVII вв. / В. В. Каргалов. - М. : Русское слово, 2002. $336 \mathrm{c}$.

14. Книга сеунчей 1613-1619 гг. / подгот. А. Л. Станиславский, С. П. Мордовина // Памятники истории Восточной Европы. Источники XVXVII вв. / под ред. Б. Н. Флори. - М. ; Варшава : Археографический центр, 1995. - Т. 1. - С. 11-98.

15. Кобзарева, Е. И. Шведский военачальник Я. П. Делагарди в России «Смутного времени» / Е. И. Кобзарева // Новая и новейшая история. 2006. - № 3. - С. 170-184.

16. Козляков, В. Н. Михаил Федорович / В. Н. Козляков. - М. : Молодая гвардия, 2010. - 384 с.

17. Козляков, В.Н.Василий Шуйский / В.Н.Козляков. - М. : Молодая гвардия, 2007. - 301 с.

18. Костомаров, Н. И. Смутное время Московского государства в начале XVII ст. / Н. И. Костомаров. - СПб., 1904. - Т. II. -410 c.

19. Pamiętniki Samuela i Bogusława Kazimierza Maskiewiczów (wiek XVII) / opr. wstępem i przypisami opatrzył A. Sajkowski, red. i słowo wstępne W. Czapliński. - Wrocław, 1961. - 332 s.

20. Новый летописец // ПСРЛ. - СПб., 1910. T. 14. - C. 96.

21. Платонов, С. Ф. Очерки по истории Смуты в Московском государстве XVI-XVII вв. / С. Ф. Платонов. - М. : Наука, 1995. - 481 с.

22. Поход его королевского величества в Москву 1609 г. // Памятники, относящиеся к Смутному времени начала XVII ст. - СПб., 1872. - Т. 1. Стб. 427-720. - (Серия «Русская историческая библиотека»).

23. Скрынников, Р. Г. Василий Шуйский / Р. Г. Скрынников. - М. : АСТ, 2002. - 400 с.
24. Соловьев, С. М. История России с древнейших времен / С. М. Соловьев // Сочинения : в 18 кн. М. : Мысль, 1989. - Кн. IV, т. 7/8. - 758 с.

25. Сюрье, В. М. Якоб Де ла Гарди / В. М. Сюрье // Сто замечательных финнов. Калейдоскоп биографий / под ред. Т. Вихавайнена ; пер. с фин. И. М. Соломеща. - Хельсинки : О-во фин. лит., 2004. $-814 \mathrm{c}$.

26. Тюменцев, И. О. Смута в России в начале XVII в.: движение Лжедмитрия II / И. О. Тюменцев. - М. : Наука, 2008. - 686 с.

27. Чтения в Обществе Истории и Древностей Российских (ЧОИДР). Год третий. 1847-1848. T. VI. -C. 1-24.

28. Шепелев, И. С. Освободительная и классовая борьба в Русском государстве в 16081610 гг. / И. С. Шепелев. - Пятигорск : Изд-во ППИ, 1957. $-559 \mathrm{c}$.

29. Andruszewicz, A. Dzieje Dymitriad 16021614 / A. Andruszewicz. - Warszawa : Akademia Nauk Społecznych «Wyd. Naukowe», 1990. - 367 s.

30. Anusik, Z. W kręgu władzyi opozycji. Kariery faworytów królewskich a kariery opozycjonistów w dobie panowania Zygmunta III (1587-1632)/Z. Anusik// Studia i szkice staropolskie. - Łódź, 2011. -S. 268-327.

31. Archiwum Państwowe w Gdańsku. Rkps. № 300. - Л. 29-74. - [Неопубликованный].

32. Biblioteka Czartoryskich w Krakowie (далеe BCz). - Rkps. № 104. - [Неопубликованный].

33. BCz. - Rkps. № 104. - Л. 805-812. - [Неопубликованный].

34. Biblioteka Jagiellońska w Krakowie (далее BJ). - Rkps. № 102. - Л. 38-50. - [Неопубликованный].

35. Biblioteka Ossolińskich we Wrocławiu (далее - BO). - Rkps. № 6603. - Л. 671-679. - [Неопубликованный].

36. Biblioteka Polskiej Akademii Nauk w Kórniku (далее- BK). - Rkps. № 1539/I. 28. Akta staropolskie różne 1587-1613. - Л. 74-75 об. - [Неопубликованный].

37. Biblioteka Raczyńskich w Poznaniu (далеe BR). - Rkps. № 33. - Л. 297об.-347 об. - [Неопубликованный].

38. Biliński, W. Janusz Porycki / W. Biliński // Polski Słownik Biograficzny. - Wrocław : Zakład Narodowy im. Ossolińskich «Wyd. Polskiej Akademii Nauk», 1983. - T. XXVII. -S. 673-675.

39. ВЈ. -Akc. 5/52. - Л. 89 об. - 126 об. - [Неопубликованный].

40. BJ. - Rkps. № 102. - Л. 321-446. - [Неопубликованный].

41. ВJ. - Rkps. № 102. - Л. 429-438. - [Неопубликованный].

42. ВJ. - Rksp. № 3596. - Л. 13-16 об. - [Неопубликованный].

43. ВJ. - Rkps. № 102. - Л. 356. - [Неопубликованный]. 
44. ВК. - Rkps. № 339. - Л. 85-90. - [Неопубликованный].

45. BR. - Rkps. № 139. - Л. 339-340. - [Неопубликованный].

46. BR. - Rkps. № 25. - Л. 4-5. - [Неопубликованный].

47. BR. - Rkps. № 390. - Л. 277-279. - [Неопубликованный].

48. Budziło, J. Wojna moskiewska wzniecona i prowadzona z okazji fałszywych Dymitrów od 1603 do 1612 / J. Budziło ; oprac. J. Byliński, J. Długosz. - Wrocław : Zakład Narodowy im. Ossolińskich, 1995. - 164 s.

49. Byliński, J. Sejm z roku 1611 / J. Byliński. Wrocław : Prace Naukowe Wydziału Prawa, Administracji i Ekonomii Uniwersytetu Wrocławskiego, 2016. $-252 \mathrm{~s}$.

50. Chłapowski, A. Urzędnicy centralni i nadworni Polski XIV-XVIII wieku : spisy / A. Chłapowski, K. Gąsiorowski. - Kraków : Wydawnictwo Instytutu Historii Polskiej Akademii Nauk, 1994. - 420 s.

51. Chynczewska-Hennel, T. Janusz Ostrogski / T. Chynczewska-Hennel // PSB. - Wrocław : Zakład Narodowy im. Ossolińskich «Wyd. Polskiej Akademii Nauk», 1979. - T. XXIV. - 812 s.

52. Czerska, D. Sprawa kandydatury królewicza Władysława na tron moskiewski (umowa 24 lutego 1610 r.) / D. Czerska // Studia Historyczne. - T. 38. 1995. - S. 310-314.

53. Darowski, A. Szkice historyczne/A. Darowski. Sankt-Petersburg, 1895. - Seria II. -345 s.

54. De la Ville, P. Krótka opowieść o tym, co się wydarzyło w Moskwie od panowania Iwana III do Szujskiego / P. De la Ville // Sienkiewicz K. Skarbiec historii polskiej. - Paryż, 1839. - T. I. -299 s.

55. Deklaracja KJMci ze strony ekspedycji moskiewskiej, w Lublinie, przez jmć podkanclerzego koronnego uczyniona // BO. - Rkps. № 12804/II. К. 111-114. - [Неопубликованный].

56. Diariusz drogi króla jmci Zygmunta III od szczęśliwego wzjazdu z Wilna pod Smoleńsk w roku 1609 a die 18 augusta i fortunnego powodzenia przez lata dwie do wzięcia zamku Smoleńska w roku 1611 / oprac. J. Byliński. - Wrocław, 1999. - 301 s.

57. Dobrowolska, W. Aleksander Bałaban / W. Dobrowolska // PSB. - Kraków : Polska Akademia Umiejętności, 1935. - T. I. - 479 s.

58. Dyariusz pisany podczas oblężenia Smoleńska p[rzez] Zygmunta III // Athenaeum Wileński. - 1842.-T. IV.-S. 82-98.

59. Dyariusz spraw pod Smoleńskiem in Januario 1610 // Biblioteka Naukowa Zakładu im. Ossolińskich. R. 1847. - T. II. - S. 409-417.

60. Dyariusz wiadomości od wyjazdu KJMci z Wilna do Smoleńska (r. 1609) // BO. - № XVII.5.III.

61. F. Simonetta do K. Borghese, 7 września 1608 r. // Biblioteka Polskiej Akademii Umiejętności Polskiej
Akademii Nauk w Krakowie. Teki Rzymskie. - Rkps. № 55. - К. 161. - [Неопубликованный].

62. Gąsiorowski, A. Urzędnicy dawnej Rzeczypospolitej XVII- XVIII wieku: spisy /A. Gąsiorowski, S. Cynarski,A. Falniowska-Gradowska. Wrocław: Zakład Narodowyim. Ossolińskich, 1990.-T. 4. Małopolska: województwa krakowskie, sandomierskie i lubelskie. - Z. 2. Urzędnicy województwa krakowskiego XVI-XVIII wieku : spisy. $-277 \mathrm{~s}$.

63. Górski, K. Oblężenie Smoleńska w latach 1609 1611 i bitwa pod Kłuszynem / K. Górski // Przewodnik Naukowy i Literacki. - 1895. - R. XXIII. - № 1. -S. 3-4. 64. Herbst, S. Aleksander Korwin Gosiewski / S. Herbst // PSB. - Wrocław : Zakład Narodowy im. Ossolińskich «Wyd. Polskiej Akademii Nauk», 1959-1960. - T. VIII. - 639 s.

65. Hirschberg, A. Maryna Mniszchówna / A. Hirshberg. - Lwów, 1906. - 354 s.

66. Historia moskiewskiej wojny prawdziwa przez mię Mikołaja Scibora z Marchocic Marchockiego pisana // Moskwa w rękach polaków. Pamiętniki dowódców i oficerów garnizonu polskiego w Moskwie w latach 1610-1612 / wybór i oprac. M. Kubala, T. Ściężor. - Bmw, 1995. - $518 \mathrm{~s}$.

67. Klemensiewicz, Z. Historia języka polskiego. III / Z. Klemensiewicz. - Warszawa : Państwowe Wydawnictwo Naukowe, 1985. - $797 \mathrm{~s}$.

68. Kobierzycki, S. Historia Władysława, królewicza polskiego i szwedzkiego / S. Kobierzycki ; wyd. J. Byliński i W. Kaczorowski. - Wrocław : Wydawnictwo Uniwersytetu Wrocławskiego, 2005. $460 \mathrm{~s}$.

69. Kupisz, D. Smoleńsk 1632-1634 / D. Kupisz.Warszawa : Bellona, 2001.-200 s.

70. Lepszy, K. Jan Daniłowicz / K. Lepszy// PSB. Kraków : Polska Akademia Umiejętności, 1938. - T. IV. S. 414-415.

71. Lepszy, K. Krzysztof Monwid Dorohostajski / K. Lepszy // PSB. - Kraków : Polska Akademia Umiejętności, 1939-1946. - T. V. -480 s.

72. Lipski, A. Jan Potocki / A. Lipski // PSB. Wrocław : Zakład Narodowy im. Ossolińskich «Wyd. Polskiej Akademii Nauk», 1984-1985. - T. XXVIII. S. 24-28.

73. List jednego z żołnierzy p. Aleksandra Zborowskiego 16 (26) lipca 1610 r. // Archiwum Główne Akt Dawnych w Warszawie. Archiwum Radziwiłłów (далее - AGAD AR). - Dz. II. - Ks. 12. - Teka 5. Nr. 557. - [Неопубликованный].

74. List P. Kuleszy // BCz. - Rkps. № 342. К. 762. - [Неопубликованный].

75. List S. Żółkiewskiego do króla Zygmunta // BR. - Rksp. № 33. - Л. 154 об.-156 об. - [Неопубликованный].

76. Maciszewski, J. Polska a Moskwa 1603-1618. Opinie i stanowiska szlachty polskiej / J. Maciszewski. - 
Warszawa : Państwowe Wydawnictwo Naukowe, 1968. $-328 \mathrm{~s}$.

77. Maciszewski, J. Szlachecka opinia publiczna w Polsce wobec interwencji w Moskwie (1604-1609) / J. Maciszewski // Kwartalnik Historyczny. Studia Sławistyczne. - Warszawa, 1963. - T. 72. - 1963. Z. 2. - S. 363-383.

78. Majewski, A. Cecora rok 1620 / A. Majewski. Warszawa : Wydawnictwo Ministerstwa Obrony Narodowej, 1970. - $254 \mathrm{~s}$.

79. Maliszewski, E. Bibliografia pamiętników polskich i Polski dotyczących. Druki i rękopisy / E. Maliszewski. - Warszawa : Towarzystwo Miłośników Historii, 1928. - 447 s.

80. Maskiewicz, S. Pamiętnik/ S. Maskiewicz // Pamiętniki Samuela i Bogusława Kazimierza Maskiewiczów (wiek XVII). - Wrocław : Ossolineum, 1961. $-332 \mathrm{~s}$

81. Niemcewicz, J. U. Dzieje panowania Zygmunta III / J. U. Niemcewicz. - Warszawa, 1819. T. II. $-608 \mathrm{~s}$.

82. Niesiecki, K. Herbarz polski / K. Niesiecki. Lipsk : Breitkopf i Haertel, 1841. - T. VIII. -652 s.

83. Niesiecki, K. Herbarz polski / K. Niesiecki. Lipsk : Breitkopf i Haertel, 1839. - T. IV. - 518 s.

84. Olgelbrand, S. Encyklopedia powszechna / S. Olgelbrand. - Warszawa, 1860. - T. III. - 528 s.

85. Pisma Stanisława Żółkiewskiego kanclerza i hetmana / wyd. A. Bielowski. - Lwów, 1861. $750 \mathrm{~s}$.

86. Polak, W. O Kreml i Smoleńszczyznę: Polityka Rzeczypospolitej wobec Moskwy w latach 1607-1612 / W. Polak // Rocznik Towarzystwa Naukowego w Toruniu. - LXXXVII. - Z. 1. - Toruń : Uniwersytet Mikołaja Kopernika w Toruniu, 1995. - 486 s.

87. Siarczyński, F. Obraz wieku panowania Zygmunta III, króla polskiego i szwiedzkiego, czyli obraz stanu narodu i kraju / F. Siarczyński. - Poznań : Księgarnia Nowa, 1858. - $405 \mathrm{~s}$.

88. Słownik geograficzny Królestwa Polskiego i innych krajów słowiańskich. - Kęs-Kutno-Warszawa : Wieku, 1883. - T. IV. - 963 s.

89. Spieralski, Z. Anonomowa relacja o bitwie pod Kłuszynem / Z. Spieralski, J. Wimmer // Wypisy źródłowe do historii polskiej sztuki wojennej. - Z. 5. Warszawa : Wydawnictwo MON, 1961.

90. Spisek Wojska Stołecznego PP. Confederatów wyszedłszy na odpoczynek na Białą Ruś i jako się położyli // AGAD AR. - Dz. II. - Ks. 12. - Л. 641642. - [Неопубликованный].

91. Summariusz żołdu wojska stołecznego moskiewskiego po rachunkom pośledniejszym w obozie pod Grodkiem uczynionym // BJ. - Rkps. № 108. - Л. 910. - [Неопубликованный].

92. W. Baranowski do W. Gembickiego, z Raciąża 20 (30) października 1608 r. // Stockholm. -
Riksarkivet. - Extranea Polen. - Rkps. № 95. -Szp. 60. [Неопубликованный].

93. Wiadomość o porażce wojska Dymitrego // BCz. - Rkps. № 342. - Л. 755-756. - [Неопубликованный].

94. Wiadomość o porażce wojska Dymitrego // BCz. - Rkps. № 105. - Nr. 41. - [Неопубликованный].

95. Wiadomość o porażce wojska Dymitrego // BR . Rksp. № 139. - Л. 376-376 об. - [Неопубликованный].

96. Żółkiewski, S. Początek i progres wojny moskiewskiej / S. Żółkiewski. - Warszawa : Państwowy Instytut Wydawniczy, 1966. - $182 \mathrm{~s}$.

\section{REFERENCES}

1. Abramovich G.V. Knyazya Shuyskie $i$ rossiyskiy tron [Princes the Shuiskys and the Russian throne]. Leningrad, Izd-vo LGU, 1991. 192 p.

2. Akty istoricheskie, sobrannye $i$ izdannye Arkheograficheskoyu komissieyu (AI) [Acts of history, collected and published by the Archaeographic Commission]. Saint Petersburg, 1841, vol. 2 , no. 282.

3. Belokurov S.A. Razryadnye zapisi za Smutnoe vremya (7113-7121 gg.) [Discharge records for the Time of Troubles (7113-7121)]. Moscow, 1907. 343 p.

4. Budila Yu. Istoriya lozhnogo Dimitriya 16031613 gg. [The history of the false Dimitry, 1603-1613]. Pamyatniki, otnosyashchiesya $k$ Smutnomu vremeni nachala XVII st. [Monuments relating to the Time of Troubles at the beginning of the $17^{\text {th }}$ century]. Saint Petersburg, 1872, vol. 1, columns 81-364.

5. Bussov K. Moskovskaya khronika 1584$1613 \mathrm{gg}$. [Moscow Chronicle of 1584-1613]. Moscow; Leningrad, Izd-vo AN SSSR, 1961. 400 p.

6. Buturlin D. Istoriya smutnogo vremeni $v$ nachale XVII v.: $v 3 t$. [History of the Time of Troubles in the beginning of the $17^{\text {th }}$ century: in 3 vols.]. Saint Petersburg, 1839, 1841, 1846, vol. III. 516 p.

7. Videkind Yu. Istoriya desyatiletney shvedskomoskovskoy voyny XVII v. [The history of the tenyear Swedish-Moscow war of the $17^{\text {th }}$ century]. Moscow, Pamyatniki istoricheskoy mysli, 2000. 652 p.

8. Verzhbovskiy F.F., ed. Voyna s Polsheyu $v$ 1609-1611 godakh [The war with Poland in 16091611]. Varshava, 1898. 102 p.

9. Delavil P. Kratkaya zapiska o tom, chto proiskhodilo $\mathrm{v}$ Moskovii ot tsarstvovaniya Ivana Vasilyevicha, imperatora, do Vasiliya Ivanovicha Shuyskogo, sochinennaya Petrom Delavillem de Lombal v 1611 godu [A short note on what happened in Muscovy from the reign of emperor Ivan Vasilyevich to Vasily Ivanovich Shuisky, composed by Peter Delaville de Lombal in 1611]. Russkiy vestnik. Tom pervyy. Saint Petersburg, 1841, pp. 744-756. 
10. Delavil P. Kratkoe rassuzhdenie o tom, chto proizoshlo v Moskovii so vremeni tsarstvovaniya Ivana Vasilyevicha, imperatora, do Vasiliya Ivanovicha Shuyskogo. Sochinenie Pyera Delavilya de Dombalya. 1611 [A brief discussion of what happened in Muscovy from the time of the reign of emperor Ivan Vasilyevich to Vasily Ivanovich Shuisky. The composition of Pierre Delaville de Dombal. 1611]. Istoriograficheskiy sbornik: mezhvuz. sb. nauch. tr. [Historiographic collection: interuniversity collection of academic works]. Saratov, Izd-vo Sarat. un-ta, 2008, iss. 23, pp. 124-139.

11. Dianova T.V., Kostyukhina L.M. Vodyanye znaki rukopisey Rossii XVII v.: (Po materialam Otdela rukopisey GIM) [Watermarks of Russian manuscripts of the $17^{\text {th }}$ century: (Based on the materials of the Department of Manuscripts of the State Historical Museum)]. Moscow, Nauka Publ., 1980, no. 1255-1257, 1261-1262.

12. Tyumentsev I.O., Yanitskiy M., Tupikova N.A., Plotnikov A.B. Dnevnik Yana Petra Sapegi (16081611 gg.) [The diary of Jan Peter Sapieha (16081611 gg.)]. Pamyatniki istorii Vostochnoy Evropy. Istochniki $X V-X V I I v v$ [Monuments of the history of Eastern Europe. Sources of the $15^{\text {th }}-17^{\text {th }}$ centuries]. Moscow; Warsaw, Drevlekhranilishche Publ., 2012, vol. $9.455 \mathrm{p}$.

13. Kargalov V.V. Moskovskie voevody XVI-XVIIvv. [The Moscow governors of the $16^{\text {th }}-17^{\text {th }}$ centuries]. Moscow, Russkoe slovo Publ., 2002. 336 p.

14. Stanislavskiy A.L., Mordovina S.P. Kniga seunchey 1613-1619 gg. [The Book of the Seboys of 1613-1619]. Flori B.N., ed. Pamyatniki istorii Vostochnoy Evropy. Istochniki XV-XVII vv. [Monuments of the history of Eastern Europe. Sources of the $15^{\text {th }}-17^{\text {th }}$ centuries]. Moscow; Warsaw, Arkheograficheskiy tsentr Publ., 1995, vol. 1, pp. 11-98.

15. Kobzareva E.I. Shvedskiy voenachalnik Ya. P. Delagardi v Rossii «Smutnogo vremeni» [Swedish military leader Ya. P. Delagardi in Russia "The Time of Troubles"]. Novaya i noveyshaya istoriya, 2006, no. 3, pp. 170-184.

16. Kozlyakov V.N. Mikhail Fedorovich. Moscow, Molodaya gvardiya Publ., 2010. 384 p.

17. Kozlyakov V.N. Vasiliy Shuyskiy. Moscow, Molodaya gvardiya Publ., 2007. 301 p.

18. Kostomarov N.I. Smutnoe vremya Moskovskogo gosudarstva $v$ nachale XVII st. [The Time of Troubles of the Moscow State in the Beginning of the $17^{\text {th }}$ Century]. Saint Petersburg, 1904, vol. II. 410 p.

19. Sajkowski A., Czapliński W. Pamiętniki Samuela i Bogusława Kazimierza Maskiewiczów (wiek XVII). Wrocław, 1961. $332 \mathrm{p}$.

20. Novyy letopisets [The New Chronicler]. PSRL. Saint Petersburg, 1910, vol. 14, p. 96.
21. Platonov S.F. Ocherki po istorii Smuty $v$ Moskovskom gosudarstve XVI-XVII vv. [Essays on the History of the Troubles in the Moscow State of the $16^{\text {th }}-17^{\text {th }}$ centuries]. Moscow, Nauka Publ., 1995. $481 \mathrm{p}$.

22. Pokhod ego korolevskogo velichestva $\mathrm{v}$ Moskvu $1609 \mathrm{~g}$. [The campaign of his royal Majesty to Moscow in 1609]. Pamyatniki, otnosyashchiesya $k$ Smutnomu vremeni nachala XVII st. [Monuments relating to the Time of Troubles at the beginning of the $17^{\text {th }}$ century]. Saint Petersburg, 1872, vol. 1, columns 427-720. (Series "Russian Historical Library”).

23. Skrynnikov R.G. Vasiliy Shuyskiy. Moscow, AST Publ., 2002. 400 p.

24. Solovyev S.M. Istoriya Rossii s drevneyshikh vremen [History of Russia from ancient times]. Sochineniya: $v 18 \mathrm{kn}$. [Works: in 18 books]. Moscow, Mysl Publ., 1989, Book IV, vol. 7/8. 758 p.

25. Syurye V.M. Jacob De la Gardi. Vikhavaynen T., ed. Sto zamechatelnykh finnov. Kaleydoskop biografiy [One hundred remarkable Finns. Kaleidoscope of biographies]. Khelsinki, O-vo fin. lit. Publ., 2004. 814 p.

26. Tyumentsev I.O. Smuta v Rossii v nachale XVII v.: dvizhenie Lzhedmitriya II [Riot in Russia in the beginning of the $17^{\text {th }}$ century: the movement of False Dmitry II]. Moscow, Nauka Publ., 2008. 686 p.

27. Chteniya v Obshchestve Istorii i Drevnostey Rossiyskikh. God tretiy [Readings in the Society of History and Antiquities of the Russian. The third year]. 1847-1848, vol. VI, pp. 1-24.

28. Shepelev I.S. Osvoboditelnaya i klassovaya borba $v$ Russkom gosudarstve v 1608-1610 gg. [Liberation and class struggle in the Russian state in 1608-1610]. Pyatigorsk, Izd-vo PPI, 1957. 559 p.

29. Andruszewicz A. Dzieje Dymitriad 1602 1614. Warszawa, Akademia Nauk Społecznych «Wyd. Naukowe», 1990. 367 p.

30. Anusik Z. W kręu władzy i opozycji. Kariery faworytów królewskich a kariery opozycjonistów w dobie panowania Zygmunta III (1587-1632). Studia $i$ szkice staropolskie. Łódź, 2011, pp. 268-327.

31. Archiwum Państwowe w Gdańsku. Rkps. no. 300, L. 29-74. [Unpublished].

32. Biblioteka Czartoryskich w Krakowie. Rkps. no. 104. [Unpublished].

33. Biblioteka Czartoryskich w Krakowie. Rkps. no. 104, L. 805-812. [Unpublished].

34. Biblioteka Jagiellońska $w$ Krakowie. Rkps. no. 102, L. 38-50. [Unpublished].

35. Biblioteka Ossolińskich we Wrocławiu. Rkps. no. 6603, L. 671-679. [Unpublished].

36. Biblioteka Polskiej Akademii Nauk w Kórniku. Rkps. no. 1539/I. 28. Akta staropolskie różne 1587-1613. L. 74-75 reverse. [Unpublished].

37. Biblioteka Raczyńskich w Poznaniu. Rkps. no. 33. L. 297-347 reverse. [Unpublished]. 
38. Biliński W. Janusz Porycki. Polski Słownik Biograficzny. Wrocław, Zakład Narodowy im. Ossolińskich «Wyd. Polskiej Akademii Nauk», 1983. vol. XXVII, pp. 673-675.

39. Biblioteka Jagiellońska w Krakowie. Akc. 5/52, L. 89-126 reverse. [Unpublished].

40. Biblioteka Jagiellońska w Krakowie. Rkps. no. 102. L. 321-446. [Unpublished].

41. Biblioteka Jagiellońska w Krakowie. Rkps. no. 102. L. 429-438. [Unpublished].

42. Biblioteka Jagiellońska w Krakowie. Rksp. no. 3596. L. 13-16 reverse. [Unpublished].

43. Biblioteka Jagiellońska w Krakowie. Rkps. no. 102. L. 356. [Unpublished].

44. Biblioteka Jagiellońska w Krakowie. Rkps. no. 339. L. 85-90. [Unpublished].

45. Biblioteka Jagiellońska w Krakowie. Rkps. no. 139. L. 339-340. [Unpublished].

46. Biblioteka Jagiellońska w Krakowie. Rkps. no. 25. L. 4-5. [Unpublished].

47. Biblioteka Jagiellońska w Krakowie. Rkps. no. 390. L. 277-279. [Unpublished].

48. Budziło J. Wojna moskiewska wzniecona $i$ prowadzona z okazji fatszywych Dymitrów od 1603 do 1612. Wrocław, Zakład Narodowy im. Ossolińskich, 1995. $164 \mathrm{p}$.

49. Byliński J. Sejm z roku 1611. Wrocław, Prace Naukowe Wydziału Prawa, Administracji i Ekonomii Uniwersytetu Wrocławskiego, 2016.252 p.

50. Chłapowski A., Gąsiorowski K. Urzędnicy centralni i nadworni Polski XIV-XVIII wieku: spisy. Kraków, Wydawnictwo Instytutu Historii Polskiej Akademii Nauk, 1994. 420 p.

51. Chynczewska-Hennel T. Janusz Ostrogski. PSB. Wrocław, Zakład Narodowy im. Ossolińskich «Wyd. Polskiej Akademii Nauk», 1979, vol. XXIV. 812 s.

52. Czerska D. Sprawa kandydatury królewicza Władysława na tron moskiewski (umowa 24 lutego 1610 r.). Studia Historyczne, 1995, vol. 38, pp. 310-314.

53. Darowski A. Szkice historyczne. Saint Petersburg, 1895. Seria II. 345 p.

54. De la Ville P. Krótka opowieść o tym, co się wydarzyło w Moskwie od panowania Iwana III do Szujskiego. Sienkiewicz K. Skarbiec historii polskiej. Paryż, 1839, vol. I. 299 p.

55. Deklaracja KJMci ze strony ekspedycji moskiewskiej, w Lublinie, przez jmć podkanclerzego koronnego uczyniona. Biblioteka Ossolińskich we Wrocławiu. Rkps. no. 12804/II. K. 111-114. [Unpublished].

56. Byliński J., ed. Diariusz drogi króla jmci Zygmunta III od szczęśliwego wzjazdu z Wilna pod Smoleńsk w roku 1609 a die 18 augusta i fortunnego powodzenia przez lata dwie do wzięcia zamku Smoleńska w roku 1611. Wrocław, 1999. 301 p.
57. Dobrowolska W. Aleksander Bałaban. PSB. Kraków, Polska Akademia Umiejętności, 1935. vol. I. 479 p.

58. Dyariusz pisany podczas oblężenia Smoleńska $\mathrm{p}$ [rzez] Zygmunta III. Athenaeum Wileński, 1842. vol. IV. pp. 82-98.

59. Dyariusz spraw pod Smoleńskiem in Januario 1610. Biblioteka Naukowa Zakładu im. Ossolińskich. R. 1847. vol. II. pp. 409-417.

60. Dyariusz wiadomości od wyjazdu KJMci z Wilna do Smoleńska (r. 1609). Biblioteka Ossolińskich we Wroctawiu. no. XVII.5.III.

61. F. Simonetta do K. Borghese, 7 września 1608 r. Biblioteka Polskiej Akademii Umiejętności Polskiej Akademii Nauk w Krakowie. Teki Rzymskie. Rkps. no. 55. K. 161. [Unpublished].

62. Gąsiorowski A., Cynarski S., FalniowskaGradowska A. Urzędnicy dawnej Rzeczypospolitej XVII-XVIII wieku: spisy. Wrocław, Zakład Narodowy im. Ossolińskich, 1990. vol. 4. Małopolska: województwa krakowskie, sandomierskie i lubelskie. Z. 2. Urzędnicy województwa krakowskiego XVIXVIII wieku: spisy. 277 p.

63. Górski K. Oblężenie Smoleńska w latach 16091611 i bitwa pod Kłuszynem. Przewodnik Naukowy $i$ Literacki, 1895, R. XXIII, no. 1, pp. 3-4.

64. Herbst S. Aleksander Korwin Gosiewski. PSB. Wrocław, Zakład Narodowy im. Ossolińskich «Wyd. Polskiej Akademii Nauk», 1959-1960. vol. VIII. 639 p.

65. Hirschberg A. Maryna Mniszchówna. Lwów, 1906. 354 p.

66. Historia moskiewskiej wojny prawdziwa przez mię Mikołaja Scibora z Marchocic Marchockiego pisana. Kubala M., Ściężor T. Moskwa w rękach polaków. Pamiętniki dowódcówi oficerów garnizonu polskiego w Moskwie w latach 1610-1612. Bmw, $1995.518 \mathrm{p}$.

67. Klemensiewicz Z. Historia języka polskiego. III. Warszawa, Państwowe Wydawnictwo Naukowe, 1985.797 p.

68. Kobierzycki S. Historia Władysława, królewicza polskiego i szwedzkiego. Wrocław, Wydawnictwo Uniwersytetu Wrocławskiego, 2005.460 p.

69. Kupisz D. Smoleńsk 1632-1634. Warszawa, Bellona, 2001.200 p.

70. Lepszy K. Jan Daniłowicz. PSB. Kraków, Polska Akademia Umiejętności, 1938. vol. IV, pp. 414-415.

71. Lepszy K. Krzysztof Monwid Dorohostajski. PSB. Kraków, Polska Akademia Umiejętności, 19391946. vol. V. 480 p.

72. Lipski A. Jan Potocki. PSB. Wrocław, Zakład Narodowy im. Ossolińskich «Wyd. Polskiej Akademii Nauk», 1984-1985. vol. XXVIII. pp. 24-28.

73. List jednego z żołnierzy p. Aleksandra Zborowskiego 16 (26) lipca 1610 r. Archiwum 
Główne Akt Dawnych w Warszawie. Archiwum Radziwiłtów. Dz. II. Ks. 12. Teka 5. Nr. 557. [Unpublished].

74. List P. Kuleszy. Biblioteka Czartoryskich $w$ Krakowie. Rkps. no. 342. K. 762. [Unpublished].

75. List S. Żółkiewskiego do króla Zygmunta. Biblioteka Raczyńskich w Poznaniu. Rksp. no. 33. L. 154-156 reverse. [Unpublished].

76. Maciszewski J. Polska a Moskwa 16031618. Opinie i stanowiska szlachty polskiej. Warszawa, Państwowe Wydawnictwo Naukowe, 1968. $328 \mathrm{p}$.

77. Maciszewski J. Szlachecka opinia publiczna w Polsce wobec interwencji w Moskwie (1604-1609). Kwartalnik Historyczny. Studia Stawistyczne. Warszawa, 1963. vol. 72, pp. 363-383.

78. Majewski A. Cecora rok 1620. Warszawa, Wydawnictwo Ministerstwa Obrony Narodowej, 1970. 254 p.

79. Maliszewski E. Bibliografia pamiętników polskich i Polski dotyczacych. Druki i rękopisy. Warszawa, Towarzystwo Miłośników Historii, 1928. $447 \mathrm{p}$.

80. Maskiewicz S. Pamiętnik. Pamiętniki Samuela i Bogusława Kazimierza Maskiewiczów (wiek XVII). Wrocław, Ossolineum, 1961. 332 p.

81. Niemcewicz J.U. Dzieje panowania Zygmunta III. Warszawa, 1819. vol. II. 608 p.

82. Niesiecki K. Herbarz polski. Lipsk, Breitkopf i Haertel, 1841. vol. VIII. 652 p.

83. Niesiecki K. Herbarz polski. Lipsk, Breitkopf i Haertel, 1839. vol. IV. 518 p.

84. Olgelbrand S. Encyklopedia powszechna. Warszawa, 1860. vol. III. $528 \mathrm{~s}$.

85. Bielowski A. Pisma Stanisława Żółkiewskiego kanclerza i hetmana. Lwów, 1861.750 p.

86. Polak W. O Kreml i Smoleńszczyznę: Polityka Rzeczypospolitej wobec Moskwy w latach 1607-1612. Rocznik Towarzystwa Naukowego w Toruniu.
LXXXVII. Z. 1. Toruń, Uniwersytet Mikołaja Kopernika w Toruniu, $1995.486 \mathrm{p}$.

87. Siarczyński F. Obraz wieku panowania Zygmunta III, króla polskiego i szwiedzkiego, czyli obraz stanu narodu i kraju. Poznań, Ksieggarnia Nowa, $1858.405 \mathrm{p}$.

88. Stownik geograficzny Królestwa Polskiego i innych krajów stowiańskich. Kęs-Kutno-Warszawa, Wieku, 1883. vol. IV. 963 p.

89. Spieralski Z., Wimmer J. Anonomowa relacja o bitwie pod Kłuszynem. Wypisyźródłowe do historii polskiej sztuki wojennej. Z. 5. Warszawa, Wydawnictwo MON, 1961.

90. Spisek Wojska Stołecznego PP. Confederatów wyszedłszy na odpoczynek na Białą Ruś i jako się położyli. Archiwum Główne Akt Dawnych w Warszawie. Archiwum Radziwiłtów. Dz. II. Ks. 12. L. 641-642. [Unpublished].

91. Summariusz żołdu wojska stołecznego moskiewskiego porachunkom pośledniejszym w obozie pod Grodkiem uczynionym. Biblioteka Jagiellońska w Krakowie. Rkps. no. 108. L. 910. [Unpublished].

92. W. Baranowski do W. Gembickiego, z Raciaża 20 (30) października 1608 r. Stockholm. Riksarkivet, Extranea Polen. Rkps. no. 95. Szp. 60. [Unpublished].

93. Wiadomość o porażce wojska Dymitrego. Biblioteka Czartoryskich w Krakowie. Rkps. no. 342. L. 755-756. [Unpublished].

94. Wiadomość o porażce wojska Dymitrego. Biblioteka Czartoryskich w Krakowie. Rkps. no. 105, Nr. 41. [Unpublished].

95. Wiadomość o porażce wojska Dymitrego. Biblioteka Raczyńskich w Poznaniu. Rksp. no. 139. L. 376-376 reverse. [Unpublished].

96. Żółkiewski S. Poczq̨ek i progres wojny moskiewskiej. Warszawa, Państwowy Instytut Wydawniczy, 1966. $182 \mathrm{p}$.

\section{Information about the Authors}

Igor O. Tyumentsev, Doctor of Sciences (History), Professor, Rector, Russian Presidential Academy of National Economy and Public Administration, Gagarina St., 8, 400005 Volgograd, Russian Federation, tijumencev@mail.ru, orcid.org/0000-0002-8762-9308

Nataliya A. Tupikova, Doctor of Sciences (Philology), Professor, Department of Russian Philological Studies, Volgograd State University, Prosp. Universitetsky, 100, 400062 Volgograd, Russian Federation, tupikova195@mail.ru, orcid.org/0000-0002-9217-8441

Stanislav V. Mirsky, Associate Junior Researcher, Russian Presidential Academy of National Economy and Public Administration, Buchantseva St., 66, 400120 Volgograd, Russian Federation, stwelt@list.ru, orcid.org/0000-0001-9026-4437 


\section{Информация об авторах}

Игорь Олегович Тюменцев, доктор исторических наук, профессор, ректор, Российская академия народного хозяйства и государственной службы при Президенте Российской Федерации, ул. Гагарина, 8, 400005 г. Волгоград, Российская Федерация, tijumencev@mail.ru, orcid.org/ 0000-0002-8762-9308

Наталия Алексеевна Тупикова, доктор филологических наук, профессор кафедры русской филологии, Волгоградский государственный университет, просп. Университетский, 100, 400062 г. Волгоград, Российская Федерация, tupikova195@mail.ru, orcid.org/0000-0002-9217-8441

Станислав Викторович Мирский, младший научный сотрудник по совместительству, Российская академия народного хозяйства и государственной службы при Президенте Российской Федерации, ул. Буханцева, 66, 400120 г. Волгоград, Российская Федерация, stwelt@list.ru, orcid.org/0000-0001-9026-4437 